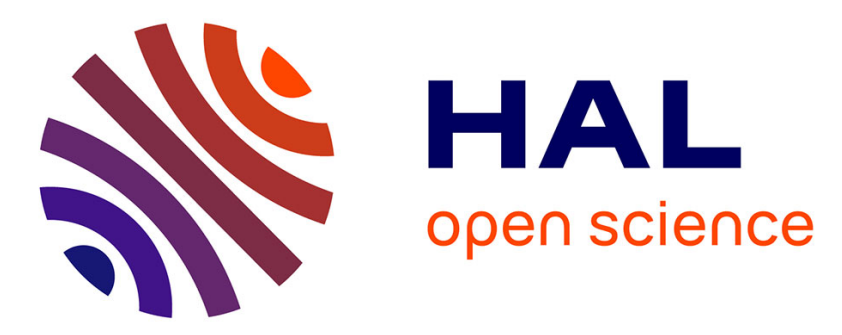

\title{
The piglet and the trident sign in osmotic demyelination syndrome
}

\author{
Alexander Balcerac, Lucia Nichelli, Sophie Demeret, Loïc Le Guennec
}

\section{To cite this version:}

Alexander Balcerac, Lucia Nichelli, Sophie Demeret, Loïc Le Guennec. The piglet and the trident sign in osmotic demyelination syndrome. Intensive Care Medicine, 2021, 10.1007/s00134-021-06354w . hal-03127697

\section{HAL Id: hal-03127697 https://hal.sorbonne-universite.fr/hal-03127697}

Submitted on 1 Feb 2021

HAL is a multi-disciplinary open access archive for the deposit and dissemination of scientific research documents, whether they are published or not. The documents may come from teaching and research institutions in France or abroad, or from public or private research centers.
L'archive ouverte pluridisciplinaire HAL, est destinée au dépôt et à la diffusion de documents scientifiques de niveau recherche, publiés ou non, émanant des établissements d'enseignement et de recherche français ou étrangers, des laboratoires publics ou privés. 


\title{
The piglet and the trident sign in osmotic demyelination syndrome
}

\author{
Alexander Balcerac 1,2, Lucia Nichelli 2,3, Sophie Demeret 1,2 and Loïc Le Guennec 1,2 \\ 1 Médecine Intensive Réanimation Neurologique, Hôpital Pitié Salpêtrière, Assistance Publique-Hôpitaux de \\ Paris, Paris, France \\ 2 Sorbonne Universités, PARIS, France \\ 3 Service de Neuroradiologie, Hôpital Pitié Salpêtrière, Assistance Publique-Hôpitaux de Paris, Paris, \\ France
}

Corresponding author: Loïc Le Guennec, MD, PhD, Médecine Intensive Réanimation Neurologique, Hôpital Pitié - Salpêtrière, 47, boulevard de l’Hôpital 75013 Paris, France Phone: +33.1.84.82.79.18 Fax: +33.1.42.16.19.89 e-mail: loic.leguennec@aphp.fr

A 28-year-old man with potomania was referred to the emergency department for confusion. On physical examination he was stuporous and had mild pyramidal syndrome. His blood sodium level was $109 \mathrm{mmol} / \mathrm{L}$. After an overly rapid correction of hyponatremia (122 $\mathrm{mmol} / \mathrm{L}$, i.e, plus $13 \mathrm{mmol} / \mathrm{L}$, in the first 12 hours), he had reduced alertness and finally developed coma on day 5 . He was intubated and mechanically ventilated. Brain magnetic resonance imaging showed prominent central pontine FLAIR-hyperintensity with peripheral and corticospinal tract sparing (Fig.1). These findings are typical of osmotic demyelination syndrome (ODS) and have been compared with a pig's snout or a trident sword (piglet sign or trident sign). One month later, he was alert with spastic teraparesis, still under mechanical ventilation.

Hypoosmolality leads to the loss of protective osmolytes that regulate cell size and prevent pathological swelling. ODS occurs after rapid osmolar shift: if the rise of serum tonicity exceeds that of intracellular space, a cell shrinking can occur, and consequently myelin membrane wrapping can separate from axons. The pons is the most prone region to ODS. To avoid this issue, targeted rate of correction should not exceed $8 \mathrm{mmol} / \mathrm{L}$ per day on any day of treatment.

\section{Figure Legend}

\section{Figure 1:}

Brain magnetic resonance imaging; the largest image is a T1 sagittal sequence demonstrating rounded hypointensity in the central pons: A. Axial T1 and FLAIR sequence showing a central pontine lesion with the appearance of a pig's snout (piglet sign). B. Coronal T1 and FLAIR sequence showing a pontine lesion with a three-pronged lance appearance (trident sign). The trident sign is classically described in the axial plane but can be easily seen also in coronal plane.

\section{Consent for publication}

Informed written consent was obtained from the patient

Funding: None

Conflicts of interest: Authors have no conflicts of interest to declare in relationship with this manuscript.

Author Contributions: LLG and AB wrote the manuscript. LN and SD critically reviewed the manuscript. 